UDK: 811.511 .141

DOI: https://doi.org/10.18485/25bghun.2021.ch4

\title{
JOHANNA LAAKSO
}

Universität Wien, Philologisch-Kulturwissenschaftliche Fakultät, Institut für Europäische und Vergleichende Sprach- und Literaturwissenschaft, Abteilung Finno-Ugristik

\section{The Place of the Hungarian Language in the World of Linguistics}

\begin{abstract}
The Hungarian language has played a decisive role in the history of Uralic language studies. Nevertheless, it is in many respects an untypical Uralic language, displaying a unique combination of genetically and areally conditioned structural features. In this paper, some examples of these features are analysed, in order to illustrate the often misunderstood complexity of historical and areal factors.
\end{abstract}

Keywords: Hungarian language, linguistic typology, European languages, Standard Average European, Uralic languages.

\section{Pre-scientific views on Hungarian}

In Hungary, as in many other European countries, the romantic nation-state project rested heavily (and partly still rests) on early relativism and what has since then been called the ethnolinguistic assumption: the idea that ethnicity is an organic whole in which language, culture, mentality and world view are interconnected. Therefore, celebrating the uniqueness of the national language was and still is an essential part of nationalist identity-building, of elevating one's own nation above others. While linguists since the $19^{\text {th }}$ century have hardly ever questioned the axiom that all natural languages, based on universal mechanisms 
of the human mind, are at the same level as concerns their power of expression, many laymen are still emotionally attached to the idea of a certain language typically, their own language - being "richer", "more complex", "more logical" or "more developed" than all the others.

The Hungarian language, completely unrelated to all its neighbours and lacking close relatives, is particularly well suited for such uniqueness myths. Interestingly enough, in Hungary these myths can happily coexist with other nonmainstream ideas about the genealogical affiliation of Hungarian, i.e. pseudolinguistic comparisons with Sumerian, Etruscan, Japanese, Old Egyptian, Turkish, or practically any language of the world. Such pseudolinguistic comparisons are often combined with conspiracy theories: the Finno-Ugric relatedness of Hungarian, it is claimed, was an evil scheme - first developed by the Habsburg rulers, then taken over by the Communists - to humiliate the proud Magyars and obliterate their true, glorious history. These ideas, a true hungaricum in that they are almost exclusively practised in Hungary or in Hungarian minority or diaspora communities, have very little to do with language or linguistics (cf. Szeverényi 2015: 121). They are motivated by a romantic, holistic view of nationhood (for studies on different aspects of this phenomenon, see Bakró-Nagy (ed.) 2018) and need not concern us here. However, the idea of Hungarian as a language exceptional in some sense is a wider question.

In the perception of non-linguists, either Hungarians or non-Hungarians, the all too obvious differences between the grammars and vocabularies of Hungarian and major European languages easily turn into evidence of the exceptional nature of Hungarian. On various Internet fora and in social media, statements to that effect, by Hungarians and non-Hungarians, are still actively circulated. For example: the mathematician János Bolyai thought of Hungarian as a "perfect" language, also because he believed it to be one of the most ancient languages in the world (Barotányi 2019); the physicist Ede (Edward) Teller credited his Hungarian mother tongue for his achievements in science, while his compatriot and colleague Leó Szilárd with his humorous remark gave rise to the mythology 
about the extraterrestrial origin of the numerous eminent Hungarian scientists in America and their mysterious language ("the Martians", Marx 2000); various foreign scientists, authors and other famous persons have praised Hungarian for its aesthetic qualities, for the exceptional richness of its lexicon or its alleged ability to express very fine semantic nuances. Examples, or even collections of examples, are easy to find with a simple Internet search; many such quotations are fabricated or misinterpreted (see e.g. elhe taifin et al. 2012).

Beyond simple nationalist motivations, this folk-linguistic exceptionalism also illustrates a more general problem: when speaking about languages, non-linguists, lacking proper terminological tools, often remain captive of metaphors taken at face value. In the popular discourse around the Hungarian language, four such metaphors often emerge and lead to questionable corollaries:

1. A language is an ethnic attribute. The Hungarian language is, above all, the marker and carrier of a Hungarian ethnic identity. It is transmitted from parents to their biological children, together with cultural and genetic features, and it is organically connected to the national mentality or the "Hungarian way of thinking". The purported exceptional features of the Hungarian language are a matter of national pride. Hungarians' particular skills in complex thinking are reflected in their language, or vice versa.

2. A language is a tool of communication. Languages can be more or less efficient, more or less useful. An "exotic" or "unique" language like Hungarian can be seen as exceptionally efficient and powerful. On the other hand, less well taught and studied languages like Hungarian, especially if they are perceived as particularly complicated and difficult to learn, have less practical value in international comparison.

3. A language is a living organism. Languages arise, grow, flourish, and then decay towards their "natural" death. Some languages are "old", others are "young"; "old" languages such as Hungarian have 
resisted decay and death more successfully than others, which proves their superiority.

\section{A language is a mechanism consisting of interconnected parts, like}

a clockwork. The construction of such a system and, therefore, language correctness as well, is a matter of logical relations.

These metaphors are not patently untrue; they are based on observations of language and language-related behaviour, and to some extent, they have even been applied in serious linguistic research. However, academic linguistics today does not accept any of them in their literal interpretation. Linguists know that languages are used in the construction of ethnic identities but they do not run in one's blood or DNA. They know that languages are used not only as tools of communication, that all natural languages in historical terms are equally young or old, that languages do not have life cycles ending with a natural death, and that rather than clockwork precision, natural languages in the course of their evolution have developed functionally unmotivated or even dysfunctional features. In particular, the wide-spread uniqueness myths are incompatible with the basic tenets of mainstream linguistics.

However, not only laymen can fall victim to myths and misinformation. It is a well-known fact that in linguistic literature, outdated and erroneous information about less well-known languages is still being circulated. Engh's (2009) collection of examples from Norwegian used in English-language general linguistic literature covers the whole spectrum from slight orthographic errors to bizarre nonsense, non-existing elements, and coarsely ungrammatical constructions. If this happens to a well-researched and cultivated Germanic language, then we can expect that a language like Hungarian, whose making and genetic backgrounds are far less widely known, will even more probably be misrepresented by wellmeaning but ignorant professional linguists.

To mention just one case: the chapter on "Hungarian and the Ugric languages" (Tambovtsev 2004) in an Encyclopedia of Linguistics issued by a renowned 
publishing house contains numerous fairly bizarre statements. For instance, the author claims that Hungarian has a great number of Slavic borrowings "especially from Slovak and Russian". Now among the indeed numerous Slavic borrowings in Hungarian, Russian lexemes are few and represent the same modern ecological, cultural and political exoticisms which are present everywhere in Europe, such as tundra (which, by the way, is a Saami loanword in Russian, see G. Bogár 2004), vodka, or kolhoz. The same article states that Hungarian only began to "develop without strong foreign influences" in 1918, after the collapse of the AustroHungarian Empire. Here, the author is not only overinterpreting a direct correlation between political independence and language contacts, he is also blissfully ignorant of the position of Hungarian as an official state language from 1844 on and of the strong puristic language planning which began already before that. These two examples should suffice to show how in the case of Hungarian, the normal quality control mechanisms of a linguistic publication can fail quite spectacularly.

\section{The Hungarian language in academic teaching and research worldwide}

Linguistics as a discipline in its own right, focusing on the structure of language independently of its artistic and rhetoric uses, was first professionalized and institutionalized during the $19^{\text {th }}$ century. These processes coincided with the development of the comparative method in historical linguistics. This, in turn, was prompted by the discovery of distant linguistic relatedness beyond intelligibility or visible similarity: the understanding of the fact that languages change with time took comparative language studies to a new level, beyond superficial comparisons between existing languages. As described in almost every handbook of historical linguistics, Sir William Jones in his famous speech in 1786 presented the crucial discovery that Latin, Greek and Sanskrit display systematic similarities which can be explained by deriving them "from some common source which, perhaps, no longer exists". In fact, János Sajnovics in his Demonstratio already in 1770 had understood the same principle in comparing Hungarian and Saami (see e.g. Stipa 
1990: 209-212), and from those very beginnings on, comparative Indo-European and comparative Finno-Ugric linguistics developed in constant interaction (see e.g. Campbell \& Poser 2008: 94). By way of its essential role in Finno-Ugric language comparisons, Hungarian, the greatest and best-known language in its language family, therefore acquired a firm position in the emerging discipline of historical linguistics in the modern sense of the word.

Outside the realm of historical-comparative linguistics, the study of the Hungarian language developed and established its position in academia largely in the same way as other modern European philologies. In the course of the professionalization of linguistic studies, gradually also dialectology and descriptive linguistics, philological studies of the written language and applied linguistics (language planning, language teaching) emerged in their institutionalized forms. The professionalization of linguistics led to the growing separation of "linguistic science" from the philological tradition, i.e. the study of texts and text-based culture. This development, however, was partly hindered or countered by ethnopolitical processes.

During the $19^{\text {th }}$ century, as mentioned above, the emerging nation-state projects often invoked holistic ideas of a romantic Volksgeist underlying both the national language and other aspects of national identity-building (cf. Leerssen 2013). In Hungary as well, while Hungarian developed into a modern state language, the study of Hungarian began to be understood as a discipline of special national importance (nemzeti tudomány; see e.g. Cser 2006). After 1920, as a reaction to the general feeling of ethno-cultural endangerment and as an academic framework for the promotion of Hungarian philology outside Hungary, the concept of Hungarologie emerged as an international field of studies. Across Europe, university departments, institutes, Hungarian seminars and Hungarian cultural centres were founded, often with the support of the state of Hungary. In parallel with these developments, the interpretations, goals, and purposes of Hungarian Studies (Hungarologie) have been discussed in a plethora of studies (see, e.g., Nádor ed. 1990, Kovács 2008). 
The academic institutionalization of Hungarian studies abroad, as with modern philologies in general, is characterized by the inevitable but uneasy union of "language" (theoretical or historical linguistics, teaching of practical language skills) and "culture" (diverse contents from political history to folk music). These elements of Hungarologie, once connected by the romantic nationalist idea of a unified Volksgeist, are now kept together by practical, financial, and political factors. Hungarian language courses are needed by linguists and literature scholars alike, while many students (again, this is typical of modern philologies in general) come to Hungarian studies driven by a holistic, often personal interest in everything Hungarian, without more specific ideas about which lines of linguistic, literary or cultural studies they might want to pursue. This kind of a holistic imagebuilding, in which Hungarian studies comprise everything connected to Hungary, therefore fits in with the interests of students and the general public. However, emphasizing the national connections may reduce Hungarian studies into a means of Hungarian cultural diplomacy and nation-branding, and this, in turn, might jeopardize the scholarly integrity and quality of research (see the debate of Sárközy 2017 and Laakso 2017).

Beyond the holistic and cultural motivations, linguistic research into Hungarian outside Hungary has typically been practised either from the viewpoint of historical-comparative linguistics, i.e. Finno-Ugric studies, or within "modern" general linguistics. The latter framework, in Hungary often termed elméleti nyelvészet ('theoretical linguistics'), is characterized by the dominance of formalist-generativist (Chomskyan) approaches, which have played a central role in Hungarian linguistics since the late 1960s - even if there are also many important and internationally renowned psycho-, socio- and cognitive linguists doing research on various aspects of the Hungarian language. (To mention but one example of the latter: the seminal work of Susan Gal (1979) on the Hungarian minority in Burgenland, Austria, is still read and quoted in numerous studies on language shift.) 
The Hungarian language, with its discourse-configurational word order and its detachable preverbs allowing for even more word order variants, and with its completely grammaticalized system of definite and indefinite articles (thanks to them, the concept of "definiteness" can be understood in a fairly simple and straightforward way), turned out to be an ideal object of study for generative linguists. From the point of view of a theory which focuses on the linear order of constituents and its interplay with the logical structure of sentences, Hungarian is particularly interesting, as its word order variation can encode not only information structure but also the scope of quantifiers and operators. An example from É. Kiss (2002: 109) shows how word order variants encode differences which in many other languages can only be expressed by adding explicit markers or rearranging the whole sentence.

(1) Sok / számos fiú felemelte a zongorát.

'Many / numerous boys (each) lifted up the piano.'

(2) Sok / számos fiú emelte fel a zongorát.

'It was many / numerous boys who lifted up the piano.'

For those linguists who see the importance and fascination of linguistics in this kind of subtleties at the interface of language and formal logic, Hungarian is indeed "a language which wears its logical form on its sleeve". This famous quip by Anna Szabolcsi (see e.g. Kenesei 2018: xiii) has been quoted in numerous studies since the 1980s and probably helped the Hungarian language to a certain fame among generative linguists around the world.

\section{Hungarian as a European language}

Even serious professional linguists seem to take pride in the fact that "Hungarian has many features unknown to [other] European languages" (Kiefer 2006). Yet, in comparison with the rest of Uralic, Hungarian often patterns with its Indo-European neighbours. Luckily, the question of "Europeanness" is no longer a matter of subjective impressions. In contrast to the tradition in which 
"European" is simply a synonym for cultural sophistication, "a club, whose membership is open only to candidates certified as suitable by the club committee" (Hobsbawm 1998: 294-295), linguistic typology since the late $20^{\text {th }}$ century has worked out a series of criteria for linguistic Europeanness.

In a number of typological studies - the best known might be the EUROTYP project of the European Science Foundation and its publications in the series Empirical Approaches to Language Typology from 1998 to 2006 - something like a core European area has emerged, with French, Dutch, and German sharing the greatest number of features (hence the term "Charlemagne Sprachbund"). The rest of Europe consists of "associated members" connected to these core varieties by a smaller number of shared features. Some European features are transparently connected to cultural history: they stem from the European tradition of literacy and translated texts, such as the Bible, or in general from the shared conventions of written literature. Already before the rise of modern linguistic typology or enterprises like "Eurolinguistics" (Hinrichs 2010) which stress the special role of language contacts and multilingualism in the evolution of linguistic Europeanness, this has been pointed out by many linguists using examples from the all-European lexicon.

In Hungarian, as in all European languages, Greek- and Latin-based internationalisms now form an essential part of the lexicon: words (biológia, fizika, autó, rádió) as well as word-formational elements or word-formation models (ex-girlfriend / ex-barátnö, transsexual / transznemü, fabrication / kitaláció...). Some lexical Europeanisms are less conspicuously present in Hungarian, as translators and language planners have replaced the original internationalisms with calques built from native elements. European language users seldom realize that compounds such as Schadenfreude / káröröm, metaphoric expressions such as benign / jóindulatú in the sense of 'not malignant, harmless (medical condition)' or fall / elesik in the sense of 'be killed in battle', or innumerable technical terms such as Eisenbahn / chemin de fer / vasút or semiconductor / félvezetö are actually part of our common European linguistic 
heritage. (Hakulinen 1969, regrettably only available in Finnish, is an excellent overview of all-European calques, including many examples from Hungarian.) In the course of a thousand years, the lexicon of Hungarian has been formed by influences, models and policies analogous to those in other European countries, by translation of religious and legal texts, by processes of technical, political and educational development and terminologization.

The effects of European literacy can also be seen in what Kortmann (1998) calls "cultural diffusion of syntax". The well-known fact that "[t]he grammar of a written language is profoundly different from that of the spoken language" (Givón 1993: 13) is largely based on the prevalence of complex and hierarchic syntactic structures in written texts. The traditions of European literacy have given rise to a variety of complex clause types, formed with various conjunctions (causal: because / mert; adversative: but / de; conditional: if / ha; complementizer: that / hogy...) and grammaticalizing multi-word connectives (for instance: provided that / azzal a feltétellel, hogy...; despite the fact that / annak ellenére, hogy...). Practically all of them are reflected in Hungarian, which - together with other "Western" Uralic languages such as Finnish or Estonian - has developed a Western-type system of finite subordination by way of conjunctions and relative pronouns. In this, Hungarian differs sharply from its Eastern relatives, in which subordinated clauses are built on non-finites (or, if finite, on conjunctions recently borrowed from Russian; see Skribnik forthcoming). Non-finite subordination is only marginally present in modern Hungarian but far more prominent in Old Hungarian texts, possibly supported by Latin models: the first preserved Hungarian text, Halotti Beszéd, has hadlaua choltat ( "hallá holtát", lit. "he heard his dying") and birsagnop ivtua ("birságnap jutva", 'judgment-day coming') where today's Hungarians would write hallotta, hogy meg fog halni 'he heard that he will die' or amikor eljön az itélet napja 'when the day of judgment comes'.

Furthermore, a strong tradition of written and official language use is probably one of the factors behind the rich all-European system of grammaticalized sentence adverbials (see, e.g., Ramat \& Ricca 1998). Hungarian shares this system 
of adverbials for evaluative (várhatóan 'expectably', szerencsére 'fortunately', remélhetöleg 'hopefully'), quotative (állitólag 'allegedly') or performative functions (ezennel 'hereby') or for the hierarchy of positive probability (alig(ha) 'hardly' < talán 'maybe' < valószínüleg 'probably' < biztosan 'certainly').

In addition to these phenomena which can be transparently connected to European traditions of literacy, Hungarian displays numerous syntactic, morphological and perhaps even phonetic features which seem to be areally conditioned in some way: they are typical of Europe but less frequent elsewhere - and often also less typical of Uralic in general. To mention but a few: Hungarian is the only Uralic language with a completely grammaticalized system of definite and indefinite articles. It is also one of the few Uralic languages with a true dative case, i.e. a case which primarily marks the recipient in a prototypic "give" construction and does not belong to a typically Uralic three-part source-locationgoal set of local cases. Furthermore, Hungarian, unlike the majority of Uralic languages but similarly to German, for example, has absolutive participles, i.e. participles which can relativize both the patient argument of a transitive verb (lopott ló-gestohlenes Pferd 'stolen horse') and the single argument of an intransitive (telic) verb (elhullott levél - gefallenes Blatt 'fallen leaf'); absolutive participles seem to be an areal phenomenon, "more common in Europe and in South America than elsewhere" (Shagal 2019: 83-84). Also the equative construction in Hungarian conforms to the core European model (see Haspelmath \& Buchholz 1998), as shown in Fig. 1.

Figure 1. Equative construction 's/he is (just) as old as I' in Hungarian and German

\begin{tabular}{|c|c|c|c|c|c|}
\hline & & $\begin{array}{c}\text { parameter } \\
\text { marker } \\
\text { (derived from a } \\
\text { demonstrative) }\end{array}$ &  & $\begin{array}{c}\text { standard marker } \\
\text { (derived from an } \\
\text { interrogative) }\end{array}$ & 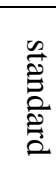 \\
\hline Hungarian & ö & (ugyan)olyan & idös & $\operatorname{mint}$ & én \\
\hline German & er/sie ist & (genau)so & alt & wie & ich \\
\hline & 's/he (is)' & 'such / so' & 'old' & 'as'< 'how' & 'I' \\
\hline
\end{tabular}




\section{Beyond and within Europe}

As shown by the examples above, Hungarian - despite its traditionally strong position in Uralic language studies - is in many respects an un-Uralic language, shaped by a long period of separate development and contacts with unrelated languages. This becomes particularly clear when comparing information structuring (expressing old or new information, focus, etc.) in Hungarian with its Ob-Ugric sister languages (cf. Skribnik and Laakso, forthcoming): on its way to Europe, Hungarian has acquired new means of information structuring, such as definite and indefinite articles, while reanalysing old ones or losing them.

An example of old techniques reanalysed is the use of the object-agreement marking on the verb ("definite conjugation", as it is slightly misleadingly called in many Hungarian grammars and textbooks): other Uralic languages having this device use it to mark object person or the topicality of the object, while in Hungarian it is (largely) conditioned by definiteness in the Standard Average European sense. An example of loss (and reorganization) is the marking of direct objects. Hungarian, like all other Uralic and most other European languages, belongs to the nominative-accusative alignment type: subjects of transitive and intransitive verbs alike are encoded in the same way, with the nominative case, and differently from direct objects. However, most other Uralic languages display the so-called differential object marking (DOM): instead of one accusative case, objects, depending on various features such as animacy, specificity or identifiability, can be in two or more different cases. Hungarian, in contrast, only has one accusative case used for practically all direct objects.

Looking more closely into the putative European features of Hungarian, one will of course notice that many of them are much more widespread and that instead of sharp boundaries, we must speak of more complicated geographic distributions of features, of greyzones and contacts of different strengths. Clausal negation is a good example. Hungarian differs from the majority of Uralic in having so-called symmetric negation, i.e. the negated clause is otherwise identical with the affirmative one, the only difference being that a negation marker (Hung. nem) is 
added. Most Uralic languages express negation asymmetrically: the negation marker is an auxiliary verb, on which the person is marked, while the main verb is always in the so-called connegative form. This system occurs in strikingly similar and etymologically cognate forms also in two peripheries of Uralic, viz. Finnic-Saami and Samoyedic, and probably goes back to Proto-Uralic.

Fig. 2. Examples of symmetric and asymmetric negation

\begin{tabular}{|lll|}
\hline Hungarian & Finnish & \\
Mari fut. & Mari juoksee. & 'Mary is running.' \\
Mari nem fut. & Mari ei juokse. & 'Mary is not running.' \\
Te futsz. & Sinä juokset. & 'You are running.' \\
Te nem futsz. & Sinä et juokse. & 'You are not running.' \\
\hline
\end{tabular}

Both symmetric and asymmetric negation occur in numerous languages worldwide; however, languages with exclusively asymmetric negation are not dominant in any part of the world, whereas symmetric negation dominates in large parts of Continental Europe and Southeast Asia (Miestamo 2013). Against this background, the Hungarian symmetric negation might look like a "Europeanism", just like the presence of definite and indefinite articles (cf. Dryer 2013) - but appearance can deceive. While other Western Uralic languages in the Finnic and Saami branches, despite numerous influences from their Indo-European neighbours, have maintained the inherited negation strategy with a negative auxiliary, the closest sister languages of Hungarian, Khanty and Mansi in Western Siberia, also use a European-style symmetric negation. If the somewhat problematic attempts to derive the clausal negation markers of all Ugric languages from the ancient Uralic negative auxiliary (see e.g. Zaicz [ed.] 2006 s.v. nem, Simoncsics 2011) are to be taken seriously, the symmetric negation in Hungarian might reflect common Ugric heritage rather than more recent European influences. 
Certain areal features of Hungarian are not merely European but characteristic of a larger area in Northern or Northwestern Eurasia. One such feature is the presence of front rounded vowels, i.e. /ö/ and /ü/, which seem to be extremely rare in Africa, India and Indochina, Oceania and the Americas but do occur in numerous more northern Eurasian languages from Breton to Yakut (Maddieson 2013). Other characteristic features which distinguish Hungarian from other Uralic languages are typical of a smaller area, but not necessarily the "Charlemagne Sprachbund". Two often-mentioned examples are the preverbs or verbal prefixes (igekötö), which (as Hungarian Finno-Ugricists often point out, see e.g. Honti 1999) have cognate parallels in Ob-Ugric but can also be explained as an Eastern Central European areal phenomenon (Kiefer 2010), and the Eastern Central European cultural lexicon. The latter is historically connected to Kakanien, the centralization of cultural and political influences in the Habsburg empire. These words come from different languages but typically occur in Hungarian, in at least some of the neighbouring Slavic idioms and in Austrian German: the words for 'cauliflower' and 'maize' are karfiol and kukorica/Kukuruz in Hungarian and Austrian German, in contrast to Blumenkohl and Mais used in Germany. (For a nice survey of lexical Kakanismen, see Newerkla 2002.)

\section{Uralic, and why labels matter}

Of course, it is not without reason that so many Europeans think of Hungarian as a language totally different from its European neighbours - whether they ascribe this to its genetic affiliation with other exotic languages such as Finnish, or simply consider Hungarian an idioma incomparabile. Hungarian does lack many features which are shared by well-known Western European languages. For instance, Hungarian does not express predicative possession with a have verb; actually, this have strategy is used only in roughly one quarter of the world's languages, it is less frequent worldwide than the so-called oblique possession (the type to which the Hungarian predicative possession also belongs; see Stassen 2013) but, interestingly, both Khanty and Mansi use a have verb to express 
possession. As there is no have verb, there cannot be a have perfect tense either, and have perfects as well are an often-mentioned typical Western European feature.

Above all, by virtue of its rich morphology and discourse-configurational word order, Hungarian is bound to express syntactic and semantic relations in a way which is completely different from Western European languages with their compact morphologies and fairly fixed word order patterns. For example, the use of verb-subject inversion to form questions (kommst du? viens-tu?), a typical "Europeanism", is incompatible with the principles of word order in Hungarian.

The noun inflection in Hungarian, including the notorious abundance of cases, is superficially different from the systems in the neighbouring Indo-European languages, which often express the same meanings with the help of prepositions. However, at a higher level, the correspondences between Hungarian local cases and Indo-European local prepositions are fairly transparent and can be reflected, for instance, in the conspicuously "Kakanian" tendency to increased use of 'upon' prepositions (German auf, Slavic $n a$ ) and the Hungarian superessive $(-(V) n)$ in the expressions of institutional locations: Austrian German auf der Universität and Czech na univerzitě correspond to Hungarian az egyetemen (Newerkla 2002: 10).

More interesting, therefore, is the use of inflectional and derivational morphology especially in verb derivation, at the border of morphology and syntax. It is here that Hungarian shows some interesting, ancient features well retained. For example, Hungarian, like most other Uralic languages, can use proprietive (e.g. nö-s 'having a wife, married (man)') and caritive derivatives (e.g. pénz-telen 'without money, penniless') to express (lack of) possession, in constructions which often correspond to predicative possession in other European languages.

(3) Mit ér az ember, ha pénztelen?

'What is a man worth if he has no money (lit. "if [he is] penniless")?'

Moreover, the proprietive and caritive derivational suffixes represent ancient heritage also as concerns their substance. A similarly ancient derivational suffix 
is the curative-causative, valency-increasing $-(t) A t$ : it is well represented throughout the Uralic language family, while in many other European languages there is no productive derivation of deverbal causatives:

(4) A fodrász rövidre vágta a hajamat. 'The hairdresser cut my hair short.' Rövidre vágattam a hajamat a fodrásszal. 'I had the hairdresser cut my hair short.'

In fact, the words of Kangasmaa-Minn (1992) about the role of derivation in Finnish also apply to Hungarian: it represents the "inconspicuous linguistic inheritance", retaining some essential aspects of the most ancient Uralic heritage.

We have come full circle and returned to where we started: holistic ideas about languages. It is not only laymen who feel tempted to think about languages as unified entities defined by their affiliation to a language family or a linguistic area. Also according to the practical experience of many linguists, "every language has a particular 'feel', a characteristic cut to its jib" (Fortson 2004: 70). Educated Europeans learning Hungarian - or Hungarian speakers who learn other European languages - will form their opinion about Hungarian as an European language on the basis of this 'feel'. Whether and how they will interpret this 'feel' in terms of genetic or areal labels such as "Uralic" or "European", whether and how they will understand the complexity behind these simple labels, will be an important issue for the future of European language education and language policies. But that is another story for another day.

\section{References}

Bakró-Nagy, Marianne (ed.) 2018. Okok és okozat. A magyar nyelv eredetéröl történeti, szociálpszichológiai és filozófiai megközelítésben. Budapest: Gondolat.

Barotányi, Zoltán 2019. Bolyai János a magyarra alapozta volna az új világnyelvet. Magyar Narancs 24. 12. 2019, https://magyarnarancs.hu/sorkoz/bolyai-janos-amagyarra-alapozta-volna-az-uj-vilagnyelvet-125585 (last access: 2019-12-27). 
G. Bogár Edit 2004. A tundrától a tundráig - Egy lapp eredetű nemzetközi vándorszó (A tundra szó etimológiája). In: Csepregi Márta-Várady Eszter (szerk.) 2004. Permiek, finnek, magyarok. Írások Szíj Enikő 60. születésnapjára. Urálisztikai tanulmányok 14. 21-24. Budapest: ELTE.

Campbell, Lyle and William Poser 2008. Language classification: History and method. Cambridge: Cambridge University Press.

Cser, András 2006. A magyar nyelvtudomány történetének áttekintése a kezdetektől a 20. század elejéig. In: Kiefer, Ferenc (ed.) Magyar nyelv. Budapest: Akadémiai Kiadó. 481-512.

Dryer, Matthew S. 2013. Definite Articles. In: Dryer, Matthew S. \& Haspelmath, Martin (eds.) The World Atlas of Language Structures Online. Leipzig: Max Planck Institute for Evolutionary Anthropology. (http://wals.info/chapter/37, last accessed on 2020-05-04.)

Elhe Taifin et al. 2017. Mit mondott Sir John Bowring a magyar nyelvröl? Nyest.hu 2012-08-27, https://www.nyest.hu/hirek/mit-mondott-sir-john-browning-amagyar-nyelvrol (last access: 2020-03-19)

Engh, Jan 2009. Defective documentation. International linguistics and Modern Norwegian. Folia Linguistica 43(2), 269-310.

Fortson IV, Benjamin W. 2004. Indo-European Language and Culture. Malden/Oxford etc.: Blackwell.

Gal, Susan 1979. Language Shift: Social Determinants of Linguistic Change in Bilingual Austria. New York: Academic Press.

Givón, Talmy 1993. English Grammar: A Function-based Introduction. Amsterdam: Benjamins.

Hakulinen, Lauri 1969. Suomen sanaston käännöslainoja. Helsinki: Suomalaisen Kirjallisuuden Seura.

Haspelmath, Martin, with Oda Buchholz 1998. Equative and similative constructions in the languages of Europe. In: van der Auwera, Johan (ed.) Adverbial constructions in the languages of Europe (EUROTYP 3). Berlin: Mouton de Gruyter, 277-334.

Hinrichs, Uwe (ed) 2010. Handbuch der Eurolinguistik. Wiesbaden: Harrassowitz.

Hobsbawm, Eric 1998. On history. London: Abacus.

Honti, László 1999. Az ugor alapnyelv - téves vagy reális hipotézis? In Marianne Bakró-Nagy, Zoltán Molnár, Zsuzsa Salánki and Mária Sipos (eds.) Ugor Mühely, 1997. szeptember 17-19 (Budapesti Uráli Műhely I). Budapest: MTA Nyelvtudományi Intézet, 19-41.

Kangasmaa-Minn, Eeva 1992. Pienimuotoinen kieliperimämme. (Summary: Our unobtrusive linguistic inheritance.) Sananjalka 34, 21-31.

Kenesei, István 2018. General introduction. In: Alberti, Gábor \& Laczkó, Tibor (eds.) Syntax of Hungarian. Nouns and noun phrases, Volume I. Amsterdam: Amsterdam University Press, xi-xxii. 
Kiefer, Ferenc 2006. A nyelvtudomány ma. Magyar Tudomány 2006/7, 800-805.

Kiefer, Ferenc 2010. Areal-typological aspects of word-formation: The case of aktionsart-formation in German, Hungarian, Slavic, Baltic, Romani and Yiddish. In Franz Rainer, Wolfgang U. Dressler, Dieter Kastovsky and Hans Christian Luschützky (eds.) Variation and Change in Morphology: Selected papers from the $13^{\text {th }}$ International Morphology Meeting, Vienna, February 2008. Amsterdam: Benjamins. 129-148.

É. Kiss, Katalin 2002. The Syntax of Hungarian. Cambridge: Cambridge University Press.

Kortmann, Bernd 1998. Adverbial subordinators in the languages of Europe. In: Van der Auwera, Johan (ed.) Adverbial constructions in the languages of Europe. Berlin: Mouton de Gruyter. 457-561.

Kovács, Magdolna 2008. Hungarian Studies: Theory and practice. In: Laakso, Johanna (ed.) Ungarischunterricht in Österreich: Perspektiven und Vergleichspunkte. I Teaching Hungarian in Austria: Perspectives and Points of Comparison. FinnoUgrian Studies in Austria 6. Wien: LIT-Verlag. 212-227.

Laakso, Johanna 2017. Castle ruins in the academic landscape of Europe? http://en.hungarologia.net/castle-ruins-in-the-academic-landscape-of-europe/ (last access: 2020-03-26.)

Leerssen, Joep 2013. Notes toward a Definition of Romantic Nationalism. Romantik: Journal for the Study of Romanticisms, 2(1), 9-35. https://doi.org/10.7146/rom.v2i1.20191

Maddieson, Ian 2013. Front Rounded Vowels. In: Dryer, Matthew S. \& Haspelmath, Martin (eds.) The World Atlas of Language Structures Online. Leipzig: Max Planck Institute for Evolutionary Anthropology. http://wals.info/chapter/11 (last access: 2020-05-04.)

Marx, György 2000. A marslakók érkezése. Budapest: Akadémiai Kiadó.

Miestamo, Matti 2013. Symmetric and Asymmetric Standard Negation. In: Dryer, Matthew S. \& Haspelmath, Martin (eds.) The World Atlas of Language Structures Online. Leipzig: Max Planck Institute for Evolutionary Anthropology. http://wals.info/chapter/113 (last access: 2020-05-04.)

B. Nádor, Orsolya (ed.) 1990. A hungarológia fogalma. Hungarológiai Ismerettár 5. Budapest: Nemzetközi Hungarológiai Központ. https://mek.oszk.hu/02000/02055/02055.htm (last access: 2020-04-12.)

Newerkla, Stefan 2002. Sprachliche Konvergenzprozesse in Mitteleuropa. In I. Pospíšil (ed.) Crossroads of Cultures: Central Europe. Kreuzwege der Kulturen: Mitteleuropa. Křžovotky kultur: Středni Evropa. Перекрестки культуры: Средняя Европа (= Litteraria Humanitas XI). Brno: Masarykova univerzita, 211-236. (Online version in the Internet journal Kakanien revisited: http://www.kakanien-revisited.at/beitr/fallstudie/SNewerkla1.pdf, last accessed 2020-05-4.) 
Ramat, Paolo and Davide Ricca 1998. Sentence adverbs in the languages of Europe. In: van der Auwera, Johan (ed.) Adverbial constructions in the languages of Europe (EUROTYP 3). Berlin: Mouton de Gruyter. 187-276.

Sárközy, Péter 2017. „Vár állott, most kőhalom...” A külföldi egyetemi magyar tanszékek múltja, jelene és...? Gondolatok a Nemzetközi Hungarológiai Társaság alapításának 40. évfordulóján. Hitel 11/2017, 68-80.

Shagal, Ksenia 2019. Participles: a typological study. Berlin: De Gruyter Mouton.

Simoncsics, Péter 2011. Az ugor tagadásról. Erdélyi Múzeum 2011/2, 152-162.

Skribnik, Elena (forthcoming). Clause combining. In Bakró-Nagy, Marianne, Laakso, Johanna \& Skribnik, Elena (eds.) The Oxford Guide to the Uralic Languages. Oxford: Oxford University Press.

Skribnik, Elena \& Johanna Laakso (forthcoming). Ugric: general introduction. In BakróNagy, Marianne, Laakso, Johanna \& Skribnik, Elena (eds.) The Oxford Guide to the Uralic Languages. Oxford: Oxford University Press.

Stassen, Leon 2013. Predicative Possession. In: Dryer, Matthew S. \& Haspelmath, Martin (eds.) The World Atlas of Language Structures Online. Leipzig: Max Planck Institute for Evolutionary Anthropology. http://wals.info/chapter/117 (last access: 2020-05-04.)

Stipa, Günter Johannes 1990. Finnisch-ugrische Sprachforschung von der Renaissance bis zum Neupositivismus. Helsinki: Finnisch-Ugrische Gesellschaft.

Szeverényi, Sándor 2015. A finnugor mítosz. In: Povedák, István \& Hubbes, László (eds.) Már a múlt sem régi...: Az új magyar mitológia multidiszciplináris elemzése. Szeged: MTA-SZTE Vallási Kultúrakutató Csoport. 119-142.

Tambovtsev, Yuri 2004. Hungarian and Ugric languages. In: Philipp Strasny (ed.) Encyclopedia of Linguistics. London: Routledge.

Zaicz, Gábor (ed.) 2006. Etimológiai szótár: Magyar szavak és toldalékok eredete. Budapest: Tinta. 


\section{A magyar nyelv a (finnugor) nyelvészeti világban}

Johanna Laakso, Universität Wien (Bécsi Egyetem), Bölcsészettudományi Kar, Európai és Összehasonlító Nyelvészeti és Irodalomtudományi Intézet, Finnugor Tanszék

\section{Összefoglaló}

A magyar nyelv meghatározó szerepet játszott az uráli nyelvek kutatásában. Mindazonáltal a magyar sok tekintetben nem tipikus uráli nyelv, mivel szerkezetében számos egyedi, genetikai és areális tényezőktől függő vonás kombinálódik. Tanulmányomban néhány ilyen tulajdonság példáit elemzem, hogy bemutassam a történeti és areális tényezők gyakran félreértett komplexitását.

Kulcsszavak: magyar nyelv, nyelvészet, nyelvrokonság, tipológia.

\section{Mesto mađarskog jezika u svetu lingvistike}

Johana Lakso, Univerzitet u Beču, Filozofski fakultet, Institut za evropsku i uporednu lingvistiku i književnost, Odsek za ugrofinske studije

\section{Sažetak}

Mađarski jezik odigrao je odlučujuću ulogu u istoriji proučavanja uralskih jezika. On je, ipak, u mnogim pogledima netipičan uralski jezik koji prikazuje jedinstvenu kombinaciju genetski i arealno uslovljenih strukturnih karakteristika. U nameri da se ilustruje često pogrešno shvaćena složenost istorijskih i arealnih faktora, u ovom radu su analizirani neki od primera tih karakteristika.

Ključne reči: mađarski jezik, jezička tipologija, evropski jezici, standardni prosečni evropski, uralski jezici. 